\title{
A DIFFERENCE IN THE IMMUNOGLOBULIN CONTENT OF SEMINIFEROUS TUBULE FLUID AND RETE TESTIS FLUID OF THE RAT
}

\author{
AARNE I. KOSKIMIES, MARTTI KORMANO AND \\ AITO LAHTI \\ Department of Anatomy and III Department of Pathology, University of Helsinki, \\ Helsinki, Finland
}

(Received 28th Fune 1971)

Seminiferous tubule fluid of the testis is unique in many respects, due to the existence of a barrier mechanism which prevents the entry of various endogenous and administered substances (for references, see Setchell, 1970). Recent studies on ram rete testis fluid obtained by catheter implantation technique (Voglmayr, Waites \& Setchell, 1966), suggest that all the individual serum proteins are present in the rete testis fluid but in much lower concentrations. The existence of a specific protein was reported by Johnson \& Setchell (1968). Assuming that the rete testis fluid might represent the fluid secreted by the seminiferous tubules, Johnson \& Setchell (1968) came to the conclusion that a very little immunoglobulin does enter into the seminiferous tubule fluid, immunoglobulin being observed in the immunoelectrophoretic study of the rete testis fluid. However, in accordance with earlier staining experiments (Kormano, 1967), recent chemical work (Tuck, Setchell, Waites \& Young, 1970) has emphasized the difference between the rete testis fluid and the primary secretion of the seminiferous tubules.

By utilizing the high resolution of the step-gradient polyacrylamide gel electrophoresis, it was found very recently that both the fluid contained by the seminiferous tubules and that collected from the rete testis contain a number of specific proteins, mainly of small molecular size (Kormano, Koskimies \& Hunter, 1971). It was also noticed that the level of serum proteins was very small in the tubule fluid but higher in the rete testis fluid. In the present study, the access of antigenic constituents of the rat serum into the seminiferous tubule fluid and the rete testis fluid were compared, since there is immunological evidence to suggest a marked difference of permeability between these two duct systems (Johnson, 1970).

Rete testis fluid was collected by ligating the efferent ducts and bloodlessly puncturing the dilated rete testis $24 \mathrm{hr}$ later. Two separate, pooled and centrifuged samples, each taken from three animals, were used. Free-flow samples of tubule fluid were obtained under pentobarbitone anaesthesia through an incision in the tunica albuginea, where one of the protruding seminiferous tubules was micropunctured with a glass capillary tube with an outer diameter of 20 to $30 \mu \mathrm{m}$. The samples of tubular fluid, 0.2 to $0.5 \mu \mathrm{l}$ each, taken from several 
tubules of four testes were pooled to make $5 \mu \mathrm{l}$. Another 5- $\mu \mathrm{l}$ pooled sample of primary secretion was obtained from another four testes, using the oil droplet technique of Tuck et al. (1970). The tubule fluid was diluted 1:10 with physiological saline and centrifuged to remove the spermatozoa. For comparison, samples of rat serum and intratesticular lymph were used. The latter was easily obtained with a glass capillary tube placed between unperforated seminiferous tubules through an incision in the tunica albuginea.

The antigenic components of the rete testis fluid and the seminiferous tubule fluid were studied using micro-method double diffusion precipitation (DDP) (Ouchterlony, 1958) and micro-immunoelectrophoresis (Scheidegger, 1955). A commercial anti-rat $\gamma$-globulin produced in goat (Hyland) was used as antiserum. Except for the seminiferous tubule fluid which was not further diluted, serum, antiserum, lymph and rete testis fluid were all diluted in seriesbeginning from the original concentrations to $1: 5,1: 10$ and $1: 15$. The commercial antibody was adsorbed with rat serum by adding enough rat serum to precipitate the serum. It was kept at $37^{\circ} \mathrm{C}$ overnight and centrifuged. Adsorbed serum was controlled with rat serum in different dilutions and did not react with it in visible amounts.

The DDP technique gave a precipitation line common to rat serum, intratesticular lymph and rete testis fluid (Plate 1), suggesting a basically similar antigenic pattern in all of them. With the seminiferous tubule fluid, either free-flow fluid or primary secretion, DDP failed to show any visible precipitation line in any of the dilutions, all of which gave a precipitation line with the rete testis fluid. Using rat serum-adsorbed antibody, no precipitation lines were formed, suggesting that there were no other precipitating components in the fluid studied than those typical of rat serum. In immunoelectrophoresis, the unconcentrated rete testis fluid gave too weak a precipitation to allow a comparative immunoelectrophoresis according to the method of Wadsworth \& Hanson (1960). The immunoelectrophoretic pattern, however, was not incompatible with the similarity of the antigenic components of the rete testis fluid and serum.

Although there certainly was an unequal amount of antigenic material in both rete testis fluid and seminiferous tubule fluid as compared with the rat serum or with intratesticular lymph, a clear precipitation line was always obtained with all dilutions of the rete testis fluid. Absence of a precipitation line with tubule fluid, therefore, suggests to us that there must be much less immunoglobulin in the secretion of the seminiferous tubules than in the rete testis fluid. This finding is compatible with the view that partial equilibration of the tubule fluid with serum occurs at the more permeable rete testis. Leakage of immunoglobulins into the rete testis may have special significance, as the potential weak point in the pathogenesis of allergic orchitis (Johnson, 1970).

This study was supported by a grant from The National Research Council for Medical Sciences, Finland. 
PLATE 1

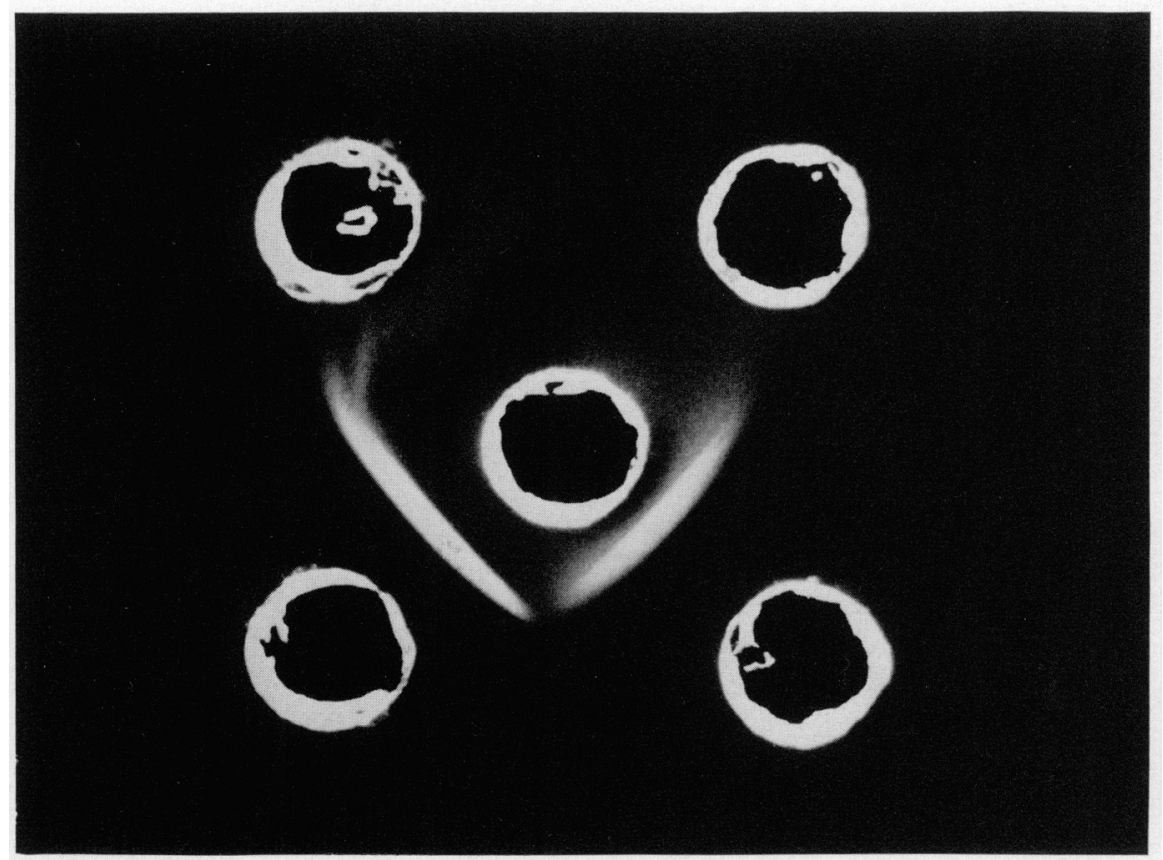

Precipitation patterns arising from the reaction between anti-rat serum in the certret

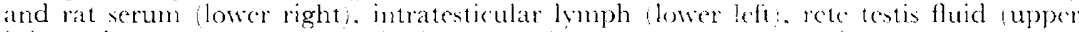
left) and seminferous tubule fluid (upper right. No visible precipitation lime appears between the seminifereus tubule Fuid and antiserum. 


\section{REFERENCES}

Johnson, M. H. (1970) An immunological barrier in the guinea-pig testis. F. Path. 101, 129.

Johnson, M. H. \& SETchell, B. P. (1968) Protein and immunoglobulin content of rete testis fluid of rams. F. Reprod. Fert. 17, 403.

Kormano, M. (1967) Dye permeability and alkaline phosphatase activity of testicular capillaries in the postnatal rat. Histochemie, 9, 327.

Kormano, M., Koskimies, A. \& Hunter, R. L. (1971) The presence of specific proteins, in the absence of many serum proteins, in the seminiferous tubule fluid of the rat testis. Experientia. (In press).

Ouchierlony, O. (1958) Diffusion-in-gel methods for immunological analysis. Prog. Allergy, 5, 1.

Scheidegger, J. J. (1955) Une micro-méthode de l'immuno-électrophorèse. Int. Archs Allergy appl. Immun. $7,165$.

Setchell, B. P. (1970) Testicular blood supply, lymphatic drainage, and secretion of fluid. In: The Testis, Vol. I. Eds. A. D. Johnson, W. R. Gomes and N. L. VanDemark. Academic Press, New York.

Tuck, R. R., Setchell, B. P., Waites, G. M. H. \& Young, J. A. (1970) The composition of fluid collected by micropuncture and catheterization from the seminiferous tubules and rete testis of rats. Pfiugers Arch. ges. Physiol. 318, 225.

Voglmayr, J. K., Waites, G. M. H. \& Setchell, B. P. (1966) Studies on spermatozoa and fluid collected directly from the testis of the conscious ram. Nature, Lond. 210, 861.

Wadsworth, C. \& Hanson, L. \&. (1960) Comparative analysis of immunoelectrophoretic precipitates employing a modified immune-electrophoretic technique. Int. Archs Allergy appl. Immun. 17,165 . 